\title{
Working Capital Strategy and Operation Risk in the Food and Beverage Companies Listed in the Indonesia Stock Exchange
}

\author{
Junaidi \\ Universitas Kader Bangsa \\ Email: junaidi120674@gmail.com
}

\begin{abstract}
The purpose of this study is to investigate the effect of working capital investment and working capital financing on the operational risk of nine listed firms in the agricultural sector of the Indonesian Stock Exchange. The time period used is 12 years from 2008 - 2019. The operational risk variable is the deviation absolute value of ROA, ROE, Sales and Cost of Goods Sold. The independent variable is the working capital investment strategy (WCIS) and Working Capital Financing Policy (WCFS). For control variables using debt ratio, size, age and current ratio variables. The analysis technique used is Ordinary Least Square (OLS) regression. The results obtained by shows that (1) WCIP have a negative and significant impact on the risk of ROA and ROE, (2) WCIP has a positive and significant effect on the risk of sales and CGS, (3) WCFP has a positive and significant impact on the risk of ROA and ROE, however, (4) WCFP has a negative and significant effect on the risk of sales and CGS. Debt ratio only has a positive effect on ROE risk. Company asset size has a positive and significant effect on Sales and CGS. Company age has a positive and significant effect on ROE risk. The current ratio variable has a positive effect on ROE risk and has a negative effect on the risk of sales and CGS.
\end{abstract}

Keywords: working capital, operation risk, food and beverage firm, Indonesia

\section{Introduction}

The management of sources and use of funds in the company can be grouped into 2 parts, namely management of short-term sources and uses of funds and management of long-term sources and uses. Management of short-term sources and uses of funds includes short-term sources such as elements in current liabilities and short-term uses includes elements in current assets. Management of sources and use of short-term funds is also known as working capital management. Working capital is part of the source and use of short-term funds (Bhunia, 2010).

This working capital is very important for the company, because this working capital element is related to the company's day-to-day activities. Therefore, working capital needs to be managed properly. According to (Appuhami, 2008) good working capital management will be able to bring companies to have the ability to compete in the market because they have a good competitive advantage (Boisjolya, Conine Jrb, \& McDonald IV, 2020).

Conversely, if working capital is managed in a bad way, it will become a major source of company bankruptcy (Dwommor \& Nasiru, 2017), it is also reported by (Largay \& Stickney, 1980) that the bankruptcy that occurred at WT Grant, a department store with a chain worldwide due to deficits in cash flow from operations that occurred in 8 out of 10 years of company operations.

Many studies have been conducted which explain that the working capital strategy used has an effect on profitability (Setianto \& Pratiwi, 2019). Investing in a lot of working capital will cause low profitability or in other words, investing in large working capital is inversely proportional to profitability or has a negative relationship with profitability. However, there are also studies that produce contradictory research such as that conducted by (Setianto \& Pratiwi, 2019) which 
found working capital has a positive influence on profitability or the greater the working capital, the greater the profitability.

In Figure 1 below, there are observations of 3 companies in the agriculture sector, namely companies with the code TBLA, SMRA, and AALI. The blue line is a development of the comparison of current assets to total assets and the red line is the ratio of net income to total sales for 20 years (2000 - 2019). The three companies for 20 years have had a current asset ratio with total assets below 50 percent, but for TBLA and SMAR the growth graph is relatively stable and increasing, while for AALI it tends to decline. However, in terms of net income, only TBLA companies have a positive net income between $0-10 \%$, while SMAR, although still positive, tends to decline, while AALI has a net income that tends to fluctuate downwards.

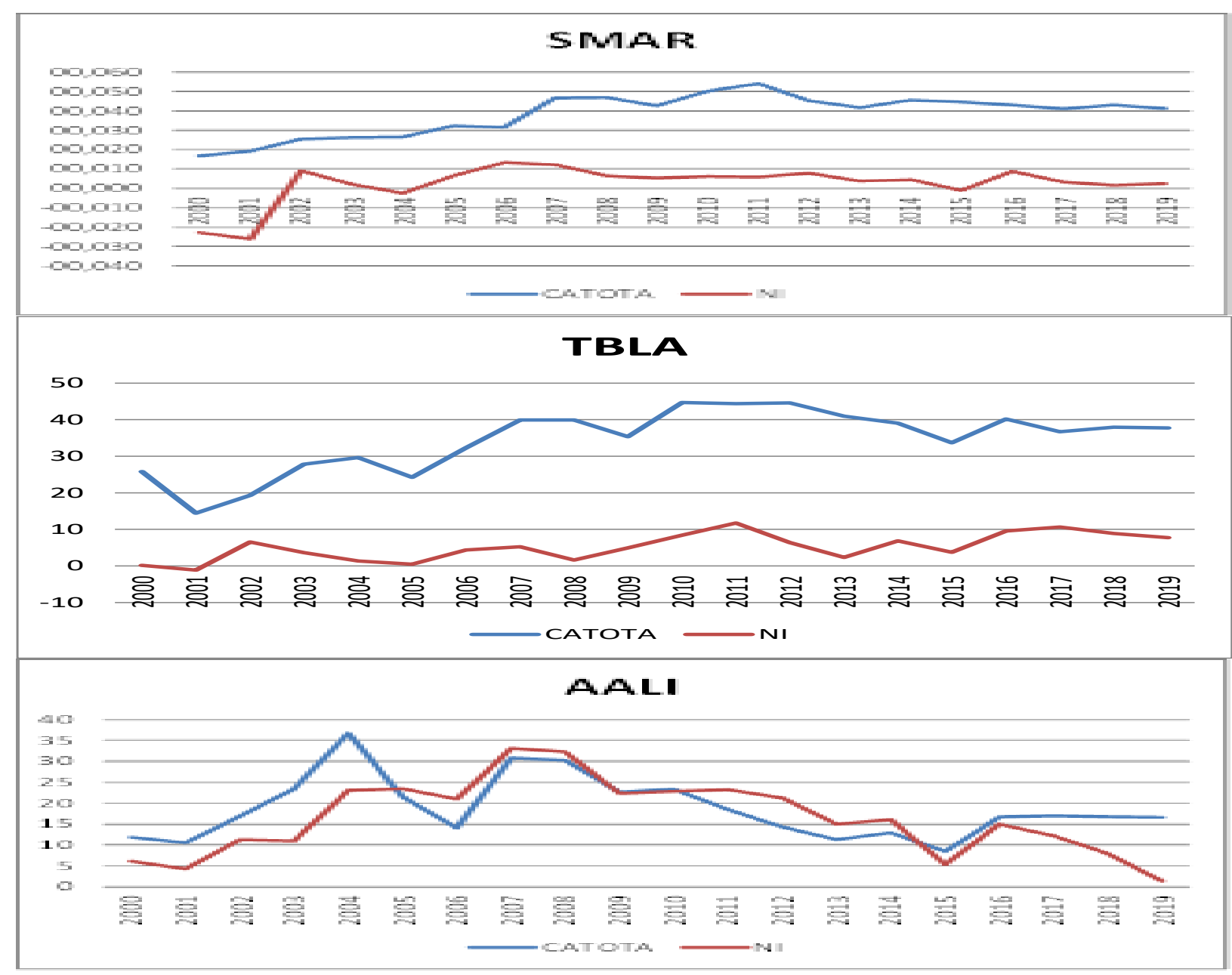

Figure 1. The ratio of current assets to total assets, and ratio of net income to total sales

From the three graphs above, it can be concluded that the development of the current ratio will be followed by the development of net income, because the development of current assets as a component of working capital will have an effect on net income. However, research on the effect of working capital on the operational risk of companies has not been carried out by many researchers. Therefore, researchers are interested in conducting research on working capital strategies implemented by these companies in relation to risk management. This working capital management strategy includes an investment working capital strategy and a working capital financing strategy, operational risks include the risk of return on assets (ROA), return 
on equity (ROE), Sales and Cost of goods sold.

\section{Literature Review}

Working capital is a short-term financial planning policy that includes investments for current assets and sources of current liabilities. (Horne \& Wachowicz, Jr, 2009). This working capital includes all current assets and current liabilities. The definition of traditional working capital is the amount of current assets available in a company or gross working capital (Brealy, Myers, \& Allen, 2014). Meanwhile, Net working capital is the difference between current assets and current liabilities (Guthman \& Huefner, 1948). From the definition of net working capital, working capital management is the management of short-term sources of funds and the use of short-term funds.

The main component of working capital from current assets can be accounts receivable arising from credit sales (Petersen \& Rajan, 1997), inventory is merchandise inventory used for sales (Kim \& Chung, 1990) and other securities (Sartoris \& Hill, 1983), while the main component of current liabilities is trade payables (Brealy, Myers, \& Allen, 2014).

The company's ability to manage receivables, inventory and current liabilities will have an effect on the company's success (Filbeck \& Krueger, 2005) and conversely, the company's inability to manage this working capital component will affect the company's difficulties in its operations (Nazir \& Afza, 2009).

\subsection{Working Capital Strategy}

The working capital strategy can be seen from two angles, the investment side of current assets and the financing angle of current debt (liabilities). Working capital from the point of view of current assets is called a working capital investment strategy (WCIS) and working capital from a financing point of view is called a working capital financing strategy (WCFS) (Weinraub \& Visscher, 1998).

A working capital investment strategy (WCIS) is a working capital investment policy measured by the ratio of current assets to total assets. If the WCIS value is lower than 0.5 indicating the degree of use of current assets is smaller than the company's fixed assets, this condition illustrates that the company uses an aggressive investment strategy (AIS), meaning that the company relies on fixed assets as a component of the company's operations. Meanwhile, if the WSIS value is greater than 0.5 , it indicates that the use of current assets is more than fixed assets, this condition is called the company using a conservative investment strategy (CIS), meaning that the company relies on working capital as the main component of business operations. (Nazir \& Afza, 2009).

An aggressive investment strategy (AIS) is concerned with active control of the company and management of current assets with the aim of minimizing it. Under this policy, current assets are only required, as they are needed to facilitate business operations. However, an aggressive investment policy results in lower current assets, lower expenses, shorter cash conversion cycles, higher risk and higher returns required to compensate for risk (Nazir \& Afza, 2009).

The working capital financing strategy (WCFS) is a policy that seeks to minimize excess liquidity while meeting short-term requirements. Companies can accept a greater risk of bankruptcy to save long-term financing costs and thus to get a greater return (Panigrahi, 2014). Working capital financing policy is measured by the ratio of short-term liabilities to total 
liabilities, where the higher the ratio value indicates the more aggressive, and the lower the value of this ratio indicates not aggressive or conservative. In other words, the SFWC has two strategies, namely an aggressive financing strategy (AFS) and a conservative financing strategy, (CFS). An aggressive financing policy (AFS) uses a higher level of current liabilities and less long-term debt (Javid \& Zita, 2014). Aggressive financing policies use higher current liabilities and lower long-term liabilities and lower capital, whereas aggressive financing policies can increase profitability. Aggressive Financing Policy is shown by the ratio between total current liabilities and total liabilities is more than 50 percent. Meanwhile, the financing policy is conservative if the SFWC value is less than 0.5. The formula for calculating a company's WCFS is as follows: total current liabilities / total liabilities.

Apart from aggressive and conservative financing, there is a moderate financing policy, a hedging funding policy. A moderate policy can be characterized by a low level of current assets as a percentage of current assets to total assets and a low level of current liabilities as a percentage of current liabilities to total liabilities or a high level of current assets as a percentage of current assets to total assets and a high level of current liabilities. High as a percentage of current liabilities of total liabilities (Brealy, Myers, \& Allen, 2014); (Horne \& Wachowicz, Jr, 2009).

Table 1 below illustrates the relationship between working capital financing strategies with the level of liquidity, profitability and risk. Conservative financing strategy, companies that have current liabilities will have high liquidity, but have low profitability due to low current liabilities that cause companies to make quick returns, besides conservative strategies have low risk, this is because These short current liabilities must be returned promptly, as opposed to long-term obligations where long returns will present a high risk of default. An aggressive financing strategy has a low liquidity and risk relationship, but has high profitability. Meanwhile, the moderate financing strategy has a relationship with liquidity, profitability and average risk.

Table 1. Resume of Working Capital Strategy

\begin{tabular}{llll}
\hline Policy & Liquidity & Profitability & Risk \\
\hline Conservative & High & Low & Low \\
Moderate & Average & Avegare & Average \\
Aggresive & Low & High & High \\
\hline
\end{tabular}

Source : (Horne \& Wachowicz, Jr, 2009)

Table 2 below shows other opinions regarding aggressive, conservative and moderate strategies conveyed by (Sierpinska \& Nesterak, 1996) explaining the relationship between each working capital investment strategy ratio with each working capital financing strategy ratio. A low CA / TA ratio with a high CL / TL ratio is an aggressive policy that will produce high returns but has a high risk, a high CA / TA ratio with a high CL / TL ratio is a conservative policy, will produce low returns but also low risk. Whereas a high CA / TA ratio with a high CL / TL ratio and a low $\mathrm{CA} / \mathrm{TL}$ ratio with a low CL / TL is a moderate policy that will produce medium returns and risks. 
Table 2. Working Capital Straegy, Risk and Return

\begin{tabular}{lll}
\hline Ratio & CA / TA Ratio & CA / TA Ratio \\
& Low & High \\
\hline CL / TL Ratio & $\begin{array}{l}\text { High Return, High Risk, } \\
\text { aggressive Policy }\end{array}$ & $\begin{array}{l}\text { Medium Return, Medium } \\
\text { Risk, Moderate policy }\end{array}$ \\
High & Medium Return, Medium & Low Return, Low Risk, \\
CL / TL Ratio & Risk, Moderate Policy & Konservative Policy \\
Low & & \\
\hline
\end{tabular}

Source: (Sierpinska \& Nesterak, 1996)

\subsection{Working Capital Strategy and Operation risk}

Operational risk is a concept related to the risk of loss resulting from failure resulting from inadequate internal processes, people and systems, or from external events. This definition includes legal risk, namely the risk of loss due to failure to comply with the law as well as precautionary measures against the destruction of ethical standards and contact agreements. It also includes exposure to litigation from all aspects of the institution's activities. The definition does not cover strategic or reputational risk.Company risk can be divided into two, namely business risk and financial risk. Business risk is the risk arising from the company's operations, while financial risk is the possibility of losses that arise due to external financing which is a fixed burden for the company. (Al-Shubiri, 2010).

This study conducted by (Hassani \& Tavosi, 2014) aims to investigate the relationship between aggressive / conservative working capital policies and the risk of profitability in companies listed on the Tehran Stock Exchange. This study used a sample of 274 companies with a time span of 7 years during the 2006-2012 period. Profitability risk is measured by the absolute deviation of ROA, ROE, ROI and ROCE. The results showed that there is a negative relationship between working capital investment policies and measures of profitability risk. In addition, there is a positive relationship between working capital financing policies and measures of profitability risk. This means that the more companies that use conservative working capital policies, the lower the risk of profitability. Conversely, the more companies that use aggressive working capital policies, the higher the risk of profitability. Anand and Gupta (2001) investigated the effect of working capital management on company risk and returns. The results show that the effectiveness of working capital management will increase the return on investment and reduce company risk. Finally, inefficient management of current assets and liabilities can lead to the bankruptcy of many companies.

Bardia (1988) found that a higher investment in working capital was associated with a reduced firm risk. And a large number of current assets and using conservative policies leads to a reduction in corporate risk (Vahid, Mohsen, \& Mohammad Reza, 2012) investigated the impact of working capital management policies (aggressive and conservative policies) on firm profitability and value. A sample of 28 Iranian Companies listed on the Tehran Stock Exchange for the 5 year period from 2005 to 2009 was selected. The results show that following a conservative investment policy and an aggressive financing policy has a negative impact on company profitability and value. This study also found that company size and company growth have a positive effect on firm profitability and value, while firm leverage shows a negative impact. 


\section{Research Method}

This study aims to determine the effect of working capital strategies on risk management. Companies that are the object of research are companies in the plantation sector which are listed on the Indonesia Stock Exchange, with 9 companies, namely with the industry code TBLA, SMAR, AALI, BWPT. The data used is data obtained from the respective company's financial statements from 2008 - 2019 or for 12 years. The dependent variable is risk management, and the independent variable is the working capital strategy. The proxy of risk management is to use absolute deviation from sales, gross profit, ROA and ROE. The independent variable for working capital investment strategy (WCIS) is obtained from total current assets divided by total assets, if the value of the WCIS is greater than 0.5, the company uses a conservative strategy. For the Working Capital Financing Policy (WCFS), it is obtained from the division between total current assets to long-term liabilities (long term debt), if the WCFP value is greater than 0.5 , then the company uses a Conservative strategy. The control variables used were debt ratio (total liabilities is divided by total assets, Ln size, age firm and current ratio (Current asset / current liabilities). The data analysis technique will use panel data regression by OLS (Fauzi, Dencik \& Asiati, 2019). The model used is as follows:

$$
\begin{aligned}
& A D_{R O A} i t=\alpha+\alpha_{1} \text { WCIS }_{i t}+\alpha_{2} \text { WCFS }_{i t}+\alpha_{3} \text { Debt }_{i t}+\alpha_{4} \text { Size }_{i t}+\alpha_{5} A G E_{i t}+\alpha_{6} C R_{i t}+\varepsilon_{i t} \\
& A D_{\text {ROE } i t}=\alpha+\alpha_{1} \text { WCIS }_{i t}+\alpha_{2} \text { WCFS }_{i t}+\alpha_{3} \text { Debt }_{i t}+\alpha_{4} \text { Size }_{i t}+\alpha_{5} A G E_{i t}+\alpha_{6} C R_{i t}+\varepsilon_{i t} \\
& A D_{\text {Sales it }}=\alpha+\alpha_{1} \text { WCIS }_{i t}+\alpha_{2} \text { WCFS }_{i t}+\alpha_{3} \text { Debt }_{i t}+\alpha_{4} \text { Size }_{i t}+\alpha_{5} A G E_{i t}+\alpha_{6} C R_{i t}+\varepsilon_{i t} \\
& A D_{C G S i t}=\alpha+\alpha_{1} \text { CCIS }_{i t}+\alpha_{2} \text { WCFS }_{i t}+\alpha_{3} \text { Debt }_{i t}+\alpha_{4} \text { Size }_{i t}+\alpha_{5} A G E_{i t}+\alpha_{6} C R_{i t}+\varepsilon_{i t} \\
& A D=\left|X_{I}-\mu\right|
\end{aligned}
$$

\section{Findings and Discussions}

The results of descriptive statistics of the variables used can be seen in table 3 below as follows:

Table 3. Descriptive Statistics

\begin{tabular}{|l|r|r|r|r|r|}
\hline & $\mathrm{N}$ & Minimum & Maximum & Mean & Std. Deviation \\
\hline FIRM & 108 & .00 & 9.00 & 4.8649 & 2.68493 \\
ROA & 108 & -.58 & .84 & .0633 & .14804 \\
ROE & 108 & -1.35 & 3.57 & .1426 & .42961 \\
SALES & 108 & 290.00 & 37391.00 & 6646.2778 & 9024.62298 \\
CGS & 108 & 174.00 & 32758.00 & 5065.8333 & 7609.97862 \\
WC Investment P & 108 & .03 & .84 & .2941 & .21903 \\
WC Financing P & 108 & .03 & 24.41 & 1.9497 & 3.04926 \\
Debt Ratio & 108 & .11 & 1.65 & .4682 & .24950 \\
Size & 108 & 6.92 & 10.29 & 8.8337 & .89129 \\
Age & 108 & 7.00 & 78.00 & 35.3889 & 19.45848 \\
Current Ratio & 108 & .10 & 8.47 & 2.0107 & 1.89533 \\
Valid N (listwise) & 108 & & & & \\
L & & & & & \\
\hline
\end{tabular}

For dependent variables such as ROA, ROE, Sales and GCS it can be explained as follows: The average value of ROA is 0.0635 or 6.35 percent, with a minimum value of - 58 or -58 percent 


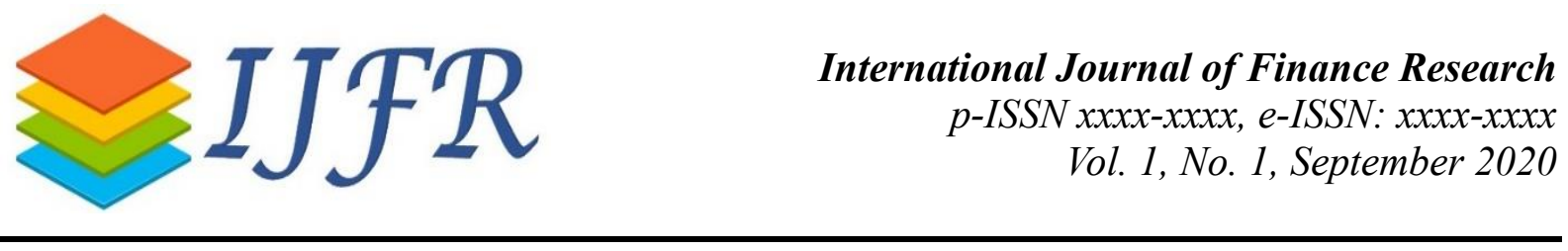

obtained by UNSP companies in 2019 and a maximum value 0.84 or 84 percent was obtained by the BISI company in 2019. The average ROE value was 0.1426 or 14.26 percent, where the minimum value was achieved by GZCO in 2016 with a value of -1.35 or -135 percent and a maximum value of 3.57 or 357 percent obtained by UNSP companies in 2017. Average Sales of Rp. 6,646 billion where the lowest sales was Rp. 290 billion was achieved by the GZCO company in 2008 and the highest sales was Rp. 37,391 billion obtained by the SMAR company in 2018. Meanwhile, the average cost of goods sold was Rp. 5,065 billion with the lowest GCS value of Rp. 174 billion was obtained by the company GZCO in 2008 and the highest GCS was Rp. 32,758 billion was obtained by the SMAR company in 2018.

Whereas for independent variables such as WCIS and WCFS it can be explained as follows: On average, the WC investment policy value is 0.2944 or 29.44 percent, meaning that the average value is below 0.5 or below $50 \%$, so it can be said This company in the Agriculture Industry uses an aggressive working capital strategy. The lowest WC investement value was 0.03 or 3 percent obtained from the GZCO company in 2018 and the highest WCIS value was 0.84 or 84 percent obtained by the BISI company in 2016. As for the working capital financing strategy (WCFS) it had an average value of 1.9494 or 194.94 percent, meaning that companies in the Agriculture Industry use aggressive financing strategies, for the lowest WCFS is 0.03 or 3 percent for BWPT companies in 2019 and the highest WCFS value is 24.41 or 2441 percent for BISI companies in 2008.

For control variables such as Debt Ratio, Size and Age, it can be explained as follows: The average value of the Debt ratio is 0.4684 or 46.84 percent, with a minimum DR value of 0.11 or 11 percent obtained by BISI company in 2010 and the value The highest DR was 1.65 or 165 percent for UNSP companies in 2019. The average company size was 8.8337, and the lowest company asset value was 6.92 or Rp. 1,016 billion was obtained by the BWPT company in 2009 and the largest asset value was SMAR in 2018 with an Ln value of 10.29 or Rp. 32,758 $\mathrm{M}$. The average age of the sample companies is 42 years and the lowest age of the company GZCO is 19 years and the oldest is 79 years old is UNSP company. The current ratio variable has an average value of 2.0107, this shows that the current assets of plantation companies are twice as large as their current liabilities. The minimum score of 0.1 was obtained by UNSP in 2019 and the maximum score of 8.47 was obtained by BISI in 2010 Working Capital Investment Policy and Working Capital Financing Policy

\subsection{Working Capital Investment Policy and Working Capital Financing Policy}

Table 4 shows the number of companies that use aggressive working capital strategies and conservative working capital strategies. 94 observations show that the company uses an aggressive investment strategy and the remaining 14 observations show that the company uses a conservative strategy. This is consistent with the WCIS average value of 0.2 . The company that used a conservative strategy during the study period was the BISI company, AALI only implemented a conservative strategy 2 times the observation, the rest of the company used an aggressive strategy. 
Table 4. Firm Strategy WCIS Crosstabulation

\begin{tabular}{|cl|l|l|l|}
\hline & & \multicolumn{2}{|l|}{ Strategy WCIS } & \multirow{2}{*}{ Total } \\
\cline { 2 - 4 } & & Konservatif & Agresif & Tot \\
\hline Firm & BISI & 12 & 0 & 12 \\
& AALI & 2 & 10 & 12 \\
& BWPT & 0 & 12 & 12 \\
& GZCO & 0 & 12 & 12 \\
& LSIP & 0 & 12 & 12 \\
& SGRO & 0 & 12 & 12 \\
& SMAR & 0 & 12 & 12 \\
& TBLA & 0 & 12 & 12 \\
Total & UNSP & 0 & 12 & 12 \\
& & 14 & 94 & 108 \\
\hline
\end{tabular}

Graph 2 below shows the distribution of the company's WCIS data, it can be seen that the data is mostly collected below 0.5 and only 3 bars have the WCIS value around 0.80 . Agriculture companies have more assets in fixed assets because they have plantation land as productive land and also have heavy machinery or vehicles that support plantation products. This suggests that the uneven distribution of WCIS data is more leftward.

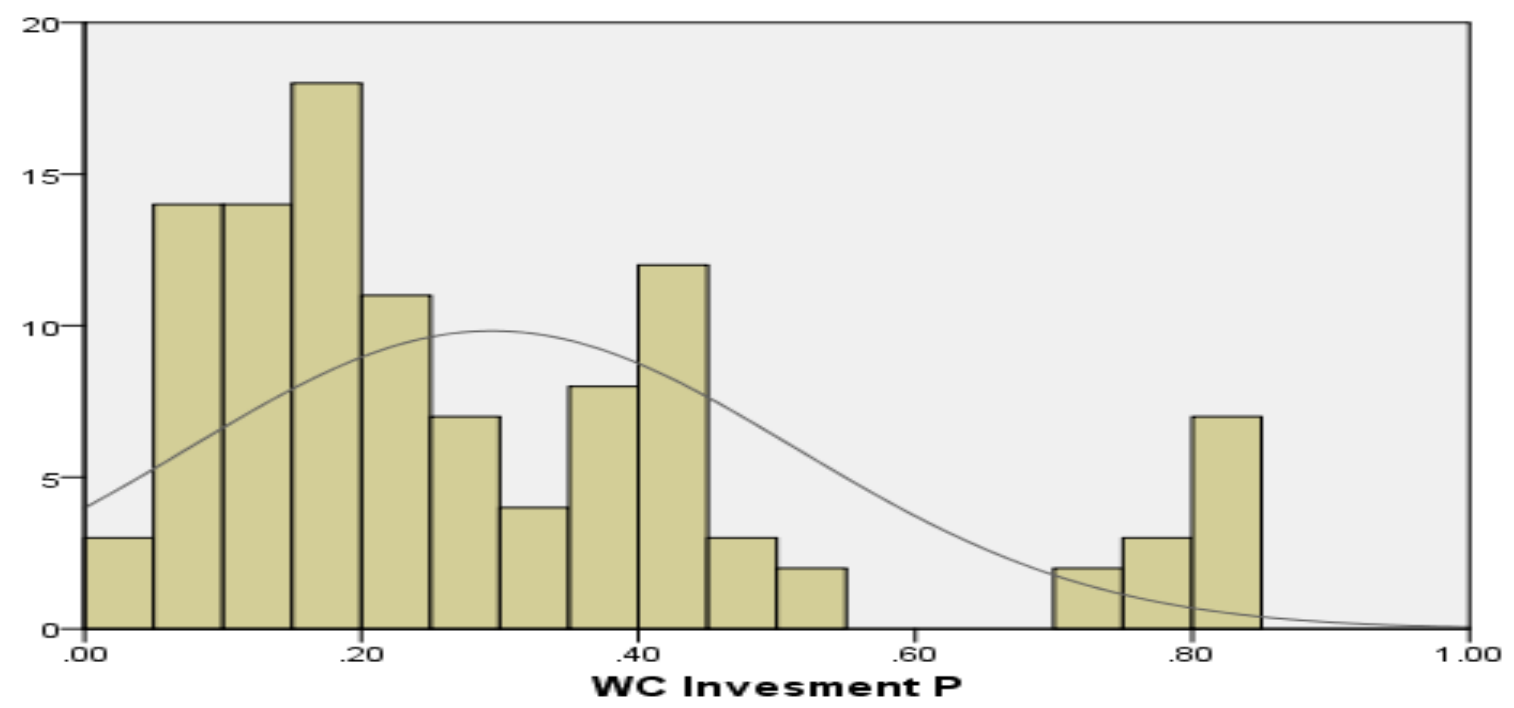

Figure 2. Graph of normal distribution of WCIP data

Table 5 below explains that for financing working capital, 75 observations or 69 percent of companies use aggressive financing strategies, and 33 observations or 31 percent of companies use conservative financing strategies. This means that companies in the agriculture sector use more short-term liabilities to finance their working capital. 
Table 5. Strategy WCFS

\begin{tabular}{|c|c|c|c|c|c|}
\hline & & Frequency & Percent & Valid Percent & $\begin{array}{l}\text { Cumulative } \\
\text { Percent }\end{array}$ \\
\hline \multirow[t]{3}{*}{ Valid } & KONSERVATIF & 33 & 30.6 & 30.6 & 30.6 \\
\hline & AGRESIF & 75 & 69.4 & 69.4 & 100.0 \\
\hline & Total & 108 & 100.0 & 100.0 & \\
\hline
\end{tabular}

Table 6 below describes companies that use a working capital financing strategy. There are 3 companies that use aggressive financing strategies for 12 years of observation period, namely BISI, AALI, and SMAR, while companies that use a conservative financing strategy for 12 years of observation period are GZCO, while companies use a combination of aggressive and conservative financing strategies.

Table 6. Firm Strategy WCFS Crosstabulation

\begin{tabular}{|cl|l|l|l|}
\hline \multirow{2}{*}{} & & \multicolumn{2}{l|}{ Strategy WCFS } & \\
\cline { 3 - 4 } & & KONSERVATIF & AGRESIF & Total \\
\hline Firm & BISI & 0 & 12 & 12 \\
& AALI & 0 & 12 & 12 \\
& BWPT & 8 & 4 & 12 \\
& GZCO & 12 & 0 & 12 \\
& LSIP & 3 & 9 & 12 \\
& SGRO & 6 & 6 & 12 \\
& SMAR & 0 & 12 & 12 \\
& TBLA & 1 & 11 & 12 \\
& UNSP & 3 & 9 & 12 \\
Total & & 33 & 75 & 108 \\
\hline
\end{tabular}

The graph below shows the spread of WCFP data, more data spreads close to zero, the results show that the current liabilities to long-term debt ratio data is more than once and below 5 times.

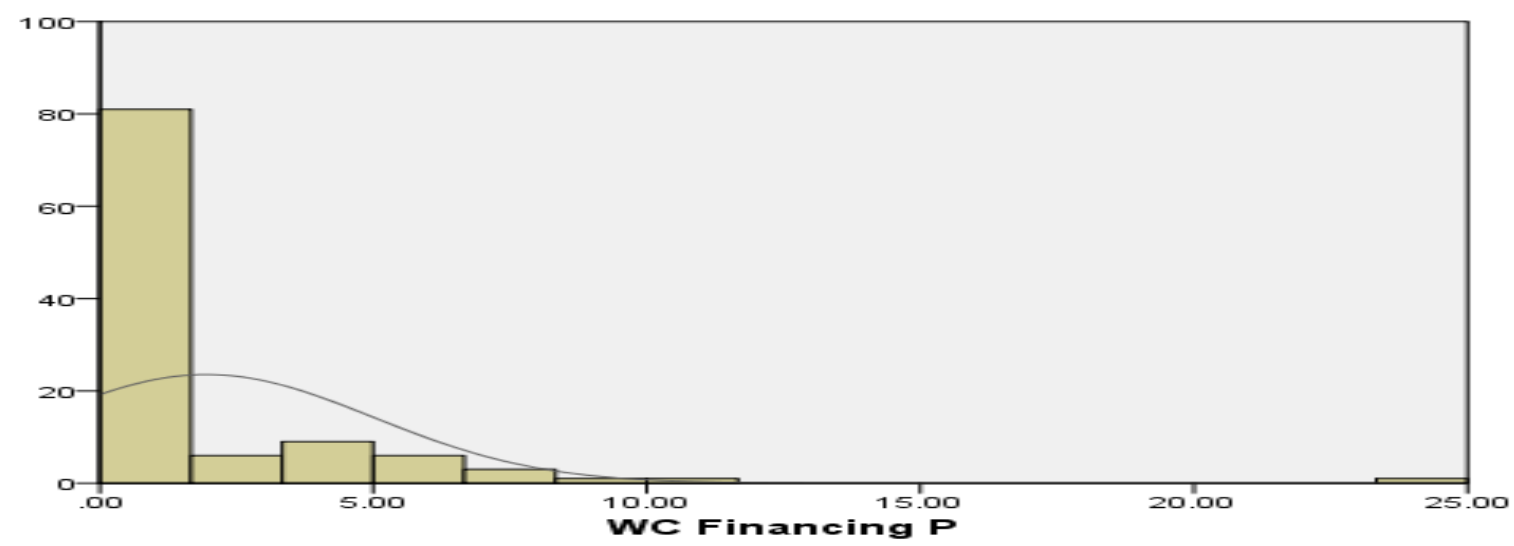

Figure 3. WCFS data distribution

Referring to the opinion Sierpinska and Nesterak (1996, there are 61 observations in which companies use low CA / TA investment strategies and high CL / TL financing strategies, so it can be said that these 61 observations use aggressive strategies which have high returns and high risks. . None of the companies used a high CA / TA investment strategy with a low CL / TL financing strategy, so there were no companies that used a conservative strategy in working 
capital management. The remaining 47 observations used a moderate strategy. Both companies that use a high working capital investment strategy with a high financing strategy or a low working capital investment strategy with a low financing strategy.

Table 7. Strategy WCFS Crosstabulation

\begin{tabular}{|c|c|c|c|c|}
\hline & & \multicolumn{2}{|c|}{ Strategy WC Inv } & \multirow[b]{2}{*}{ Total } \\
\hline & & \begin{tabular}{|l|} 
CA/TA Low \\
Agressive
\end{tabular} & $\begin{array}{l}\text { CA/TA High } \\
\text { Conservative }\end{array}$ & \\
\hline \multirow[t]{3}{*}{ Strategy WC Fin } & $\begin{array}{l}\text { CL/TL High } \\
\text { Agressive }\end{array}$ & 61 & 14 & 75 \\
\hline & $\begin{array}{l}\text { CL/TL Low } \\
\text { Conservative }\end{array}$ & 33 & 0 & 33 \\
\hline & & 94 & 14 & 108 \\
\hline
\end{tabular}

Below are 9 graphs that describe the development of the company's WCIS and WCFS during the 9 years of observation.

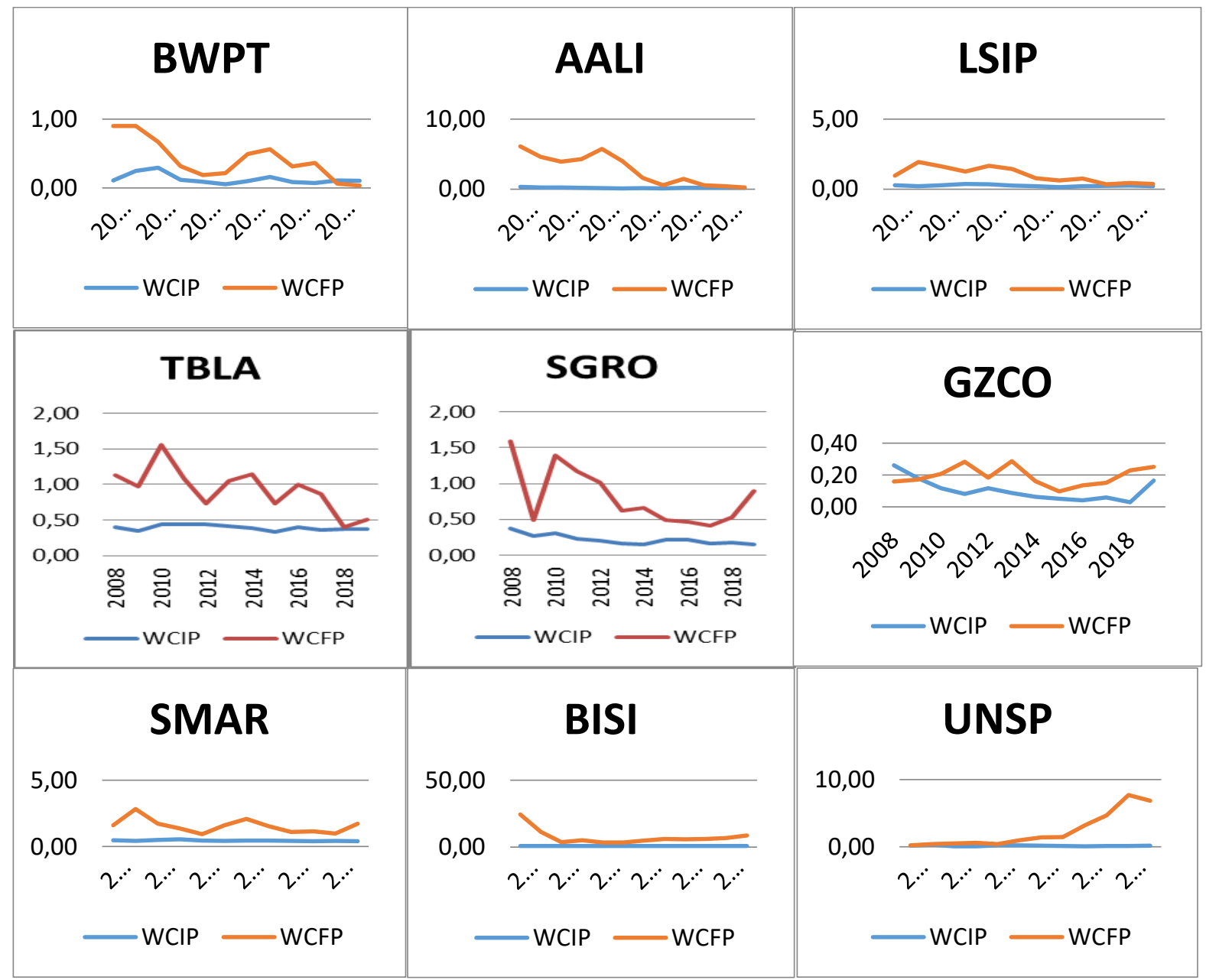

Figure 4. Graph of WCIP (WCIS) and WCFP (WCFS)

The graph above illustrates that, there are 4 companies (BWPT, AALI, LSIP, TBLA) that have decreased WCFS values, meaning that the use of short-term debt from the four companies is decreasing or the use of long-term debt is increasing. Meanwhile, WCIS for the four companies, only BWPT companies which fluctuate relatively high. Meanwhile, 4 companies (SGRO, 
GZCO, SMAR and BISI) have had WCIS values that have increased in recent years. In the graph, only SMAR companies have a relatively high WCIS value approaching 0.5 , this shows that current and fixed asset users are relatively balanced. Only one UNSP company has an increasing WCFS value in recent years, meaning that the use of short-term debt is increasing.

\subsection{Working Capital Strategy and Operational Risk}

This study uses 4 models, where the dependent variable consists of operational risk which is measured from the absolute deviation of ROA, ROE, Sales and CGC. The results are presented in table 8 below:

Table 8. Regression Results for Working Capital Strategy with Operational Risk

\begin{tabular}{|c|c|c|c|c|c|c|c|c|}
\hline \multirow{2}{*}{$\begin{array}{l}\text { Kar dep } \\
\text { Var Ind }\end{array}$} & \multicolumn{2}{|c|}{ SD ROA } & \multicolumn{2}{|c|}{ SD ROE } & \multicolumn{2}{|c|}{ SD SALES } & \multicolumn{2}{|l|}{ SD CGS } \\
\hline & Koef & Sig & Koef & Siq & Koef & Siq & Koef & Siq \\
\hline Constanta & .120 & .432 & .239 & .604 & -28488. & .000 & -23858. & .000 \\
\hline WCIP & -.170 & .039 & -.822 & .001 & 20678.9 & .000 & 18234.5 & .000 \\
\hline WCFP & .019 & .000 & .043 & .002 & -445.34 & .037 & -411.79 & .030 \\
\hline DEBT & .114 & .057 & .646 & .000 & 2511.99 & .377 & 1697.17 & .503 \\
\hline LN SIZE & -.013 & .432 & -.054 & .287 & 3670.16 & .000 & 3015.900 & .000 \\
\hline $\mathrm{AGE}$ & .000 & .616 & .004 & .049 & -60.431 & .085 & -40.183 & .197 \\
\hline $\mathrm{CR}$ & 0.13 & .190 & .059 & .053 & -898.34 & .063 & -794.577 & .065 \\
\hline $\mathrm{R}^{\wedge} 2$ & .208 & & .284 & & .337 & & .324 & \\
\hline $\mathrm{F}$ & 4.430 & $.001^{\mathrm{b}}$ & 6.672 & $.000^{\mathrm{b}}$ & 8.565 & $.000^{\mathrm{b}}$ & 8.052 & $.000^{\mathrm{b}}$ \\
\hline
\end{tabular}

Working capital investment policy has a negative and significant impact on ROA and ROE risks. This illustrates that if the WCIS ratio is greater, it means that the company uses a conservative strategy, it will have an effect on reducing the company's operational risk ROA and ROE, or the spread deviation from the average ROA and ROE will decrease. This is because many current asset investments are not productive. Based on the WCIS average data of 0.2944, this shows that the agriculture industry is using an aggressive working capital strategy, because the WCIS value is below 0.5 .

Working capital investment policy has a positive and significant effect on the risk of Sales and Cost of Goods Sold. This illustrates that if the WCIS ratio is getting bigger, it means that the company uses a conservative strategy, it will have an effect on the increase in the operational risk of the sales company and CGS or the deviation of the spread of the average sales and CGS will increase. This is because a lot of current asset investments, especially inventory and a lot of sales policies, will make the company more ready to sell. Based on the WCIS average data of 0.2944 , this shows that the agriculture industry is using an aggressive working capital strategy, because the WCIP value is below 0.5. Low WCIS value or plantation companies are more likely to invest in non-current assets such as productive plantation land and fixed assets such as plantation vehicles and processing machines. Therefore, if the company diverts more investment to investment in current assets, the risk of deviation in sales and CGS will also increase, this is because plantation products that have not been processed are easily damaged which can reduce the quality of plantation product processing as well as limited sales.

The Working Capital Financing Strategy has a positive and significant impact on ROA and ROE. This shows that the greater use of short-term financing will be able to increase the risk of ROA and ROE or the deviation of the spread of ROA and ROE from the average will be as good. In this agriculture industry the average WCFS is 1.94 , meaning that this agriculture 
industry company uses an aggressive financing strategy. This short-term financing has a fast turnaround, so it can lead to failure in payments to suppliers or creditors, thus causing a greater risk of achieving ROA and ROE.

Meanwhile, the effect of working capital financing policy has a negative and significant effect on sales and GCS. This means that if the short-term financing is greater, the risk of selling and GCS will be smaller. The Agriculture Industry uses an aggressive strategy, where short-term debt financing is more than long-term debt.

For the Debt ratio, only the risk of ROE is positive and significant, while the other variables, although influential, are not significant. This shows that the greater the use of debt, the greater the risk of ROE. The average debt ratio value in the agriculture industry is .4684 or $46.84 \%$, although this shows that the company's total debt value is still smaller than its equity value. However, this value is closer to $50 \%$ or the debt value is equal to the equity value. Therefore, an increase in debt will increase the risk on ROE.

Size only has a positive and significant effect on sales and CGS risks. This means that the greater the assets owned by the company, the greater the risk to sales and CGS. This working capital is directly related to sales and cost of goods sold. The bigger the company's assets, the more the bargaining power position, so that it can easily make sales policies and large inventory availability will make the company's sales run smoother without having to run out of inventory, likewise with purchases from suppliers, large company sizes can have a good bargaining position towards suppliers. However, large assets with a strong bargaining power position will make the risk of selling even greater and so also GCS will have a large risk, meaning that the deviation of sales and CGS on average sales and CGS is also getting bigger. Size, although it has a negative effect, is not significant. Large company size will make the deviation of ROA and ROE from the average smaller, but not significant.

Company age only affects ROA, which has a positive effect on ROE. This means that the older the company is, the greater the deviation of ROE from its average. The older the company, the owner reduces his ownership in the company, this will lead to control over the company. Company age has a negative and significant effect on alpha $10 \%$, this shows that the older the company is, the smaller the risk of sales deviation from the average, this can be because older companies are more familiar with consumers so that consumers trust more. The variable current ratio has a negative and significant effect on alpha 10 percent on the risk of sales and CGS alone. The bigger the current ratio, this means the more current assets in the company or the more liquid the company is. This large amount will cause many current assets to be idle, so that the risk of deviating sales and CGD from the average is getting smaller, indicating that the availability of large amounts of accounts receivable and sales can be managed properly, so that the risk to sales and CGS can be reduced. The effect of CR on the risk of ROA and ROE is positive but not significant. This is because the current asset is a component of short-term WCIP and WCFP, so it does not directly affect the components of total assets and equity directly.

\section{Conclusion}

WCIS has a negative and significant impact on ROA and ROE risks, meaning that an increase in investment in current assets will cause a decrease in the spread deviation (risk) on ROA and ROE. However, WCIP has a positive and significant effect on sales and CGS risks, meaning that an increase in investment in working capital will cause a deviation in the spread (risk) of 
sales and CGS to be even greater. WCFS has a positive and significant impact on ROA and ROE risks, meaning that an increase in investment in current assets will lead to an increase in risk on ROA and ROE. However, WCFS has a negative and significant effect on sales and CGS risks, meaning that an increase in investment in working capital will cause the risk of sales and CGS to be smaller as well. The debt ratio only has a positive effect on ROE risk, meaning that an increase in total debt will increase ROE risk. The size of company assets has a positive and significant effect on Sales and CGS, this means that increasing the number of company assets will cause an increase in risk on sales and CGS. Company age has a positive and significant effect on ROE risk, meaning that the older the company is, the greater the risk of ROE. The current ratio variable has a positive effect on ROE risk and has a negative effect on the risk of sales and CGS at 10 percent alpha. This illustrates that the greater the current ratio, the greater the deviation of ROE risk, and the larger the current asset, the lower the risk to sales and CGS.

\section{References}

Anand, M., \& Gupta, C. (2001). Working Capital Performance of Corporate India. Management and Accounting Research, 4(4), 35 - 65.

Appuhami, B. (2008). The impact of firms' capital expenditure on working capital management: an empirical study across industries in Thailand. International Management Review, 8 - 21.

Bardia, S. E. (1988). Working Capital Management. Point, 56, 84 - 89.

Bhunia, A. (2010). A Study of Liquidity trends on prive sector steel companies in India. Asian Journal of Management Research, 618 - 628.

Boisjolya, R. P., Conine Jrb, T. E., \& McDonald IV, M. B. (2020). Working capital management: Financial and valuation impacts,. Journal of Business Research, 8, 1-8.

Brealy, R. A., Myers, S. C., \& Allen, F. (2014). Principle of Corporate Finance. New York: Mc-Graw Hill Education.

Charitou, M., Lois, P., \& Santoso, H. B. (2012). The Relationship Between Working Capital Management And Firm's Profitability: An Empirical Investigation For An Emerging Asian Country. International Business \& Economics Research Journal, 11(8), 839 - 848.

Dwommor, J. Y., \& Nasiru, I. (2017). Do Firms Manage Working Capital for Survival or for Success: An Empirical Evidence from Literature Review? The International Journal of Business \& Management, 15(4), 173 - 183.

Fauzi, F., Dencik, A. B., \& Asiati, D. I. (2019). Metodologi Penelitian Untuk Manajemen dan Akuntansi. Jakarta: Salemba Empat.

Filbeck, G., \& Krueger, T. M. (2005). An Analysis of Working Capital Management Results Across Industries. American Journal of Business, 20(2), 11 - 20.

Guthman, H. G., \& Huefner, R. J. (1948). Corporate Financial Policy (2nd ed.). New York: Prentice Hall. Inc.

Hassani, M., \& Tavosi, A. R. (2014). To survey the effect of working capital policies (investing $\&$ financing) on profitability risk (evidence from Tehran stock exchange). Journal of Investment and Management, 3(1), 30 - 36.

Horne, J. C., \& Wachowicz, Jr, J. M. (2009). Fundamentals of Financial Management. United Kingdom: Prentice Hall. 
Javid, S., \& Zita, V. P. (2014). Impact of Working Capital Policy on Firm's Profitability: A Case of Pakistan Cement Industry. Research Journal of Finance and Accounting, 5(5), 182 - 2919.

Kim, Y. H., \& Chung, K. H. (1990). An integrated evaluation of investment in inventory and credit: a cash flow approach. Journal of Business Finance \& Accounting, 17(3), 381 - 389.

Largay, J., \& Stickney, C. (1980). Cash Flows, Ratio Analysis and the W. T. Grant Company Bankruptcy. Journal of Financial Management and Analysis, 12, 51 - 54.

Mansoori, E., \& Muhammad, D. J. (2012). The effect of working capital management on firm's profitability: Evidence from Singapore. INTERDISCIPLINARY JOURNAL OF CONTEMPORARY RESEARCH IN BUSINESS, 4(5), 472 - 486.

Nazir, M. S., \& Afza, T. (2009). Working Capital Requirements and the Determining Factors in Pakistan,. The IUP Journal of Applied Finance, 15(4), 28 - 38.

Panigrahi, A. K. (2014). Understanding the Working Capital Financing Strategy (A Case Study of Lupin Limited). Journal of Management Research and Analysis, 1(1), 100 - 102.

Petersen, M. A., \& Rajan, R. G. (1997). Trade Credit: Theories and Evidence. The Review of Financial Studies, 10(3), 661 - 691.

Sartoris, W. L., \& Hill, N. C. (1983). A Generalized Cash Flow Approach to Short-Term Financial Decisions. The Journal of Finance, 38(2), 349 - 360.

Setianto, R. H., \& Pratiwi, A. (2019). Working Capital Management in Indonesia. Gadjah Mada International Journal of Business, 21(1), 1 - 18.

Sierpinska, M., \& Nesterak, J. (1996). Przedsiebiorstwo na rynku kapitalowym. Wydawnictwo Uniwersytetu Lodzkiego, 197 - 206.

Vahid, T. K., Mohsen, A. K., \& Mohammadreza, E. (2012). The Impact of Working Capital Management Policies on Firm's Profitability and Value: Evidence from Iranian Companies. International Research Journal of Finance and Economics, 88, 155 - 162.

Weinraub, H. J., \& Visscher, S. (1998). Industry practice relating to aggressive conservative working capital policies. Journal of Financial and Strategic Decision, 11(2), 11 - 18.

\section{Copyrights}

Copyright for this article is retained by the author(s), with first publication rights granted to the journal.

This is an open-access article distributed under the terms and conditions of the Creative Commons Attribution license (http://creativecommons.org/licenses/by/4.0/) 